\title{
PENERAPAN METODE CERTAINTY FACTOR UNTUK SISTEM PAKAR DIAGNOSA PENYAKIT DIABETES MELITUS PADA RSUD BUMI PANUA KABUPATEN POHUWATO
}

\author{
Annahl Riadi \\ annahlriadi@gmail.com \\ Universitas Ichsan Gorontalo
}

\begin{abstract}
Abstrak
Diabetes Melitus (DM) atau biasa disebut diabetes merupakan penyakit gangguan metabolik menahun akibat pankreas tidak memproduksi cukup insulin atau tubuh tidak dapat menggunakan insulin yang diproduksi secara efektif. Penderita Diabetes Melitus di Kabupaten Pohuwato mengalami peningkatan sebanyak $8,5 \%$ setiap Tahun. Sistem pakar adalah program komputer yang menirukan penalaran seorang pakar dengan keahlian pada suatu wilayah pengetahuan tertentu. Sistem pakar mencoba mencari solusi, memberikan saran atau kesimpulan yang konsisten terhadap permasalahan yang ditemukannya. Penelitian ini akan dirancang menggunakan Aplikasi Dreamweaver dan bahasa pemrograman PHP, serta database MySQL. Harapan penulis, sistem ini dapat membantu masyarakat dalam mendiagnosa penyakit Diabetes Melitus. Melalui aplikasi ini, pengguna dapat melakukan konsultasi dengan sistem layaknya berkonsultasi dengan seorang pakar untuk mendiagnosa gejala yang terjadi pada pengguna serta menemukan solusi atas permasalahan yang dihadapi. Hasil pengujian sistem diperoleh nilai Cylomatic complexity $=5$ dengan jumlah Region $(R)=5, \operatorname{Node}(N)=10$, Edge $(E)=13$ Predicate Node $(P)=4$
\end{abstract}

Kata Kunci: Sistem Pakar, Diebetes Melitus, Certainty factor.

\section{Pendahuluan}

Dibetes Melitus sering di sebut dengan The Great Imitator, yaitu penyakit yang mengenai semua organ tubuh dan menimbulkan berbagai macam keluhan. Penyakit ini timbul secara perlahan, sehingga seseorang tidak menyadari bahwa adanya berbagai macam perubahan pada dirinya. Perubahan seperti minum lebih banyak, buang air kecil menjadi lebih sering, berat badan terus menurun, dan berlangsung cukup lama, biasanya tidak diperhatikan, hingga baru di ketahui setelah kondisi menurun dan setelah dibawa ke rumah sakit lalu di periksa kadar glukosa darahnya [1].

Penderita Diabetes Melitus di Kabupaten Pohuwato mengalami peningkatan sebanyak 8,5\% setiap Tahun. Pada tahun 2013 Jumlah penderita diabetes Melitus sebanyak 215, tahun 2014 sebanyak 222, sedangkan di tahun 2015 sebanyak 233. Dalam Diabetes Atlas edisi ke enam tahun 2014 yang dikeluarkan oleh International Diabetes Federation (IDF), jumlah penderita DM semakin bertambah 2 Menurut estimasi IDF (2014) 8,3\% penduduk di seluruh Dunia mengalami DM, prevalensi ini meningkat dari tahun 2011 yaitu 7,0\% dan diprediksikan pada tahun 2035 prevalensi DM akan meningkat menjadi $10,0 \%$. Diperkirakan proporsi penderita DM yang tidak terdiagnosis adalah sebesar $46,3 \%$. Satu dari dua penderita diabetes tidak mengetahui bahwa mereka telah terkena penyakit tersebut. Fenomena tersebut memerlukan upaya efektif untuk mencegah terjadinya luka pada penderita DM.

Dalam menetapkan suatu diagnosa dalam bidang kedokteran dibutuhkan alat bantu seperti aplikasi kecerdasan buatan, oleh karena itu dibuatlah sebuah sistem pakar untuk mendiagnosis penyakit Diabetes Melitus. Dalam penelitian ini membahas tentang Diabetes Melitus, tidak membahas diagnosis banding yang serupa dengan Diabetes Melitus. Diharapkan setelah dibuat sistem ini memudahkan dokter mendiagnosis Diabetes Melitus karena Diabetes Melitus merupakan salah satu penyakit yang susah untuk didiagnosis.

Penelitian ini umumnya ditujukan pada permasalahan yang cenderung ingin mendapatkan solusi dari hasil berupa konsultasi, diagnosis, estimasi, prediksi dan sejenisnya. Seperti halnya penerapan dalam dunia kedokteran ataupun dunia medis, konsultasi, dan diagnosis sangatlah diandalkan karena hasil diagnosis ini dapat mengantisipasi beberapa jenis penyakit dengan tepat dan cepat. Demikian halnya dengan Rumah Sakit yang tentu sangat mengharapkan adanya area penambahan nilai, produktivitas serta manajerial dengan dukugan hasil diagnosis penyakit Diabetes Melitus dengan tepat dan akurat sehingga kerugian dapat dicegah.

Metode pengembangan yang digunakan dalam merancang sistem ini adalah metode prototipe, dan dalam perancangannya berupa pertanyaan-pertanyaan yang menyangkut gejala Diabetes Melitus 


\section{Jurnal IImiah ILKOM Volume 9 Nomor 3 Desember 2017}

dan hasil dari pemeriksaan laboratorium berupa tampilan di dalam perangkat lunak yang dibuat lalu diberikan terapi kepada pasien yang terkena Diabetes Melitus.

Kelebihan dari sistem ini adalah dapat membantu dokter dalam menentukan diagnosis Diabetes Melitus terhadap seorang pasien. Certainty Factor yang merupakan suatu strategi pengambian keputusan dengan factor kepastian Secara sederhana dapat dijelaskan, agar pengguna dapat berdialog dengan sistem pakar yang di rancang dengan sedemikian rupa sehingga mempermudah pengguna didalam berkomunikasi dengan sistem pakar. Sistem pakar akan memberikan pertanyaan yang memerlukan jawaban 'ya' atau 'tidak' atau dengan beberapa pilihan jawaban serta pertanyaan solusi yang di berikan sistem pakar bersifat anjuran dari tiap-tiap gejala yang terjadi. Adapun terdapat kelemahan dalam mendapatkan pengetahuan, dimana pengetahuan tidak bisa didapatkan dengan mudah, karena pendekatan yang dimiliki pakar berbeda-beda dan memerlukan biaya yang sangat besar untuk pengembangan dan pemeliharaannya. Untuk itu pada penelitian iniakandirancang sistem dengan judul "Penerapan Metode Certainty FactorSistem Pakar DiagnosaPenyakit Diabetes Melitus Pada RSUD Bumi Panua Kabupaten Pohuwato".

\section{Metode}

\section{Sistem Pakar}

Menurut Nita Merlina dan Rahmat Hidayat [2], beberapa definisi sistem pakar menurut beberapa ahli yaitu sebagai berikut:

1. Menurut Durkin: Sistem pakar adalah suatu program komputer yang dirancang untuk memodelkan kemampuan penyelesaian masalah yang dilakukan seorang pakar.

2. Menurut Ignizo: Sistem pakar adalah suatu model dan prosedur yang berkaitan, dalam suatu domain tertentu, yang mana tingkat keahliannya dapat dibandingkan dengan keahlian seorang pakar.

3. Menurut Giarratano dan Riley: Sistem pakar adalah suatu sistem komputer yang bisa menyamai ataumeniru kemampuan seorang pakar

Berikut ini adalah manfaat dan kemampuan sistem pakar :

1. Meningkatkan output dan produktivitas.

2. Menurunkan waktu pengambilan keputusan.

3. Meningkatkan kualitas proses dan produk.

4. Menyerap keahlian langka.

5. Fleksibilitas.

6. Operasi peralatan yang lebih mudah.

7. Eliminasi kebutuhan peralatan yang mahal.

8. Transfer pengetahuan ke lokasi terpencil

Sistem pakar menjadi populer karena sangat banyak manfaat yang diberikannya, antara lain [3]:

a. Meningkatkan produktivitas, karena sistem pakar dapat bekerja lebih cepat dari pada manusia.

b. Membuat seseorang yang awam bekerja layaknya seorang pakar.

c. Meningkatkan kualitas, dengan memberi nasehat yang konsisten dan mengurangi kesalahan.

d. Dapat dihandalkan, sebab sistem pakar tidak pernah merasa bosan, kelelahan, ataupun sakit.

\section{Certainty Factor}

Teori Certainty Factor (CF) mengakomodasi ketidakpastian pemikiran (inexact reasoning) seorang pakar. Seorang pakar (misalnya dokter) seringkali menganalisis informasi yang ada dengan ungkapan seperti "mungkin", "kemungkinanp besar", "hampir pasti". Untuk mengakomodasi hal ini kita menggunakan certainty factor (CF) guna menggambarkan tingkat keyakinan pakar terhadap masalah yang sedang dihadapi [3]. Metode „Net belief " yang diusulkan oleh E.H. Shortliffe dan B.G.Buchanan.

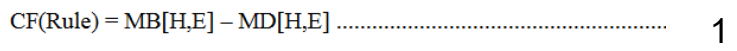

$$
\begin{aligned}
& \operatorname{MB}(\mathrm{H}, \mathrm{E})=\left\{\begin{array}{c}
1 \\
\mathrm{P}(\mathrm{H})=1 \\
\frac{\max [\mathrm{P}(\mathrm{H} \mid \mathrm{E}), \mathrm{P}(\mathrm{H})]-\mathrm{P}(\mathrm{H})}{\max [1,0]-\mathrm{P}(\mathrm{H})}
\end{array}\right. \text { lainnya ............... }
\end{aligned}
$$

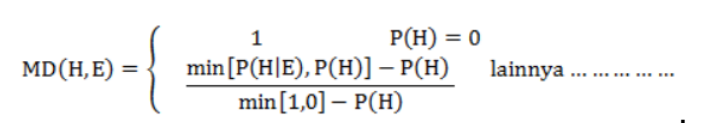

Dimana :

CF (Rule) : Faktor kepastian 
MB $(\mathrm{H}, \mathrm{E})$ : Measure Of Belief (Ukuran kepercayaan) terhadap hipotesis $\mathrm{H}$, jika diberikan evidence $E$ (antara 0 dan 1$)$.

MD (H.E) : Measure Of Disbelief (Ukuran ketidakpercayaan) terhadap evidence $H$, jika diberikan evidence $\mathrm{E}$ (antara 0 dan 1$)$.

$\mathrm{P}(\mathrm{H}) \quad$ : Probabilitas kebenaran hipotesis $\mathrm{H}$.

$\mathrm{P}(\mathrm{H} \mid \mathrm{E}) \quad$ : Probabilitas bahwa $\mathrm{H}$ benar karena faktor $\mathrm{E}$.

\section{Diabetes Melitus}

Menurut American Diabetes Melitus Association (ADA) tahun 2010, Diabetes Melitus Melitus merupakan suatu kelompok penyakit metabolik dengan karakteristik hiperglikemia yang terjadi karena kelainan sekresi insulin, kerja insulin, atau kedua-duanya [4].

Meskipun terdapat perbedaan angka prevalensi, laporan keduanya menunjukkan adanya peningkatan jumlah penyandang Diabetes Melitus Melitus (DM) sebanyak 2-3 kali lipat pada tahun 2030. Berbagai keluhan dapat ditemukan pada penyandang Diabetes Melitus. Kecurigaan adanya Diabetes Melitus Melitus (DM) perlu dipikirkan apabila terdapat keluhan klasik seperti di bawah ini [4] :

- Keluhan klasik DM berupa: poliuria, polidipsia, polifagia, dan penurunan berat badan yang tidak dapat dijelaskan sebabnya

- Keluhan lain dapat berupa: lemah badan, kesemutan, gatal, mata kabur, dan disfungsi ereksi pada pria, serta pruritus vulvae pada wanita

Secara klinis diagnosis diabetes mellitus dapat dilakukan oleh adanya gejala yang khas, yaitu :

- Rasa haus berlebihan

- Sering kencing

- Sering mengalami infeksi berulang

- Berat badan turun tanpa sebab yang jelas

- Pada kasus berat adanya penurunan kesadaran sampai koma.

Diagnosis diabetes mellitus tidak bisa ditegakkan dengan satu kali pemeriskaan glukosa darah tanpa gejala yang klasik akan tetapi perlu konfirmasi dari geja;anya dan pemeriksaan glukosa darah dilai kesempatan.

\section{Hasil dan Pembahasan}

\subsection{Analisis Sistem}

Berikut Hasil Analisis Sistem yang Berjalan dimana Pasien Mengunjungi Rumah Sakir untuk melakukan Pemeriksaan berdasarkan gejala yang diderita, selanjutnya Pasien Melakukan Registrasi. Setelah proses registrasi selesai Dokter melakukan pemeriksaan berdasarkan penyebab dan gejala yang dialami pasien, Hasil Diagnosa Dokter dijelaskan kepasien untuk segela ditindak lanjuti baik melalui pemberian obat ataupun melakukan pemeriksaan lanjutan. Hasil diagnosa pasien diteruskan ke pihak pimpinan sebagai laporan dan rekam medik pasien.

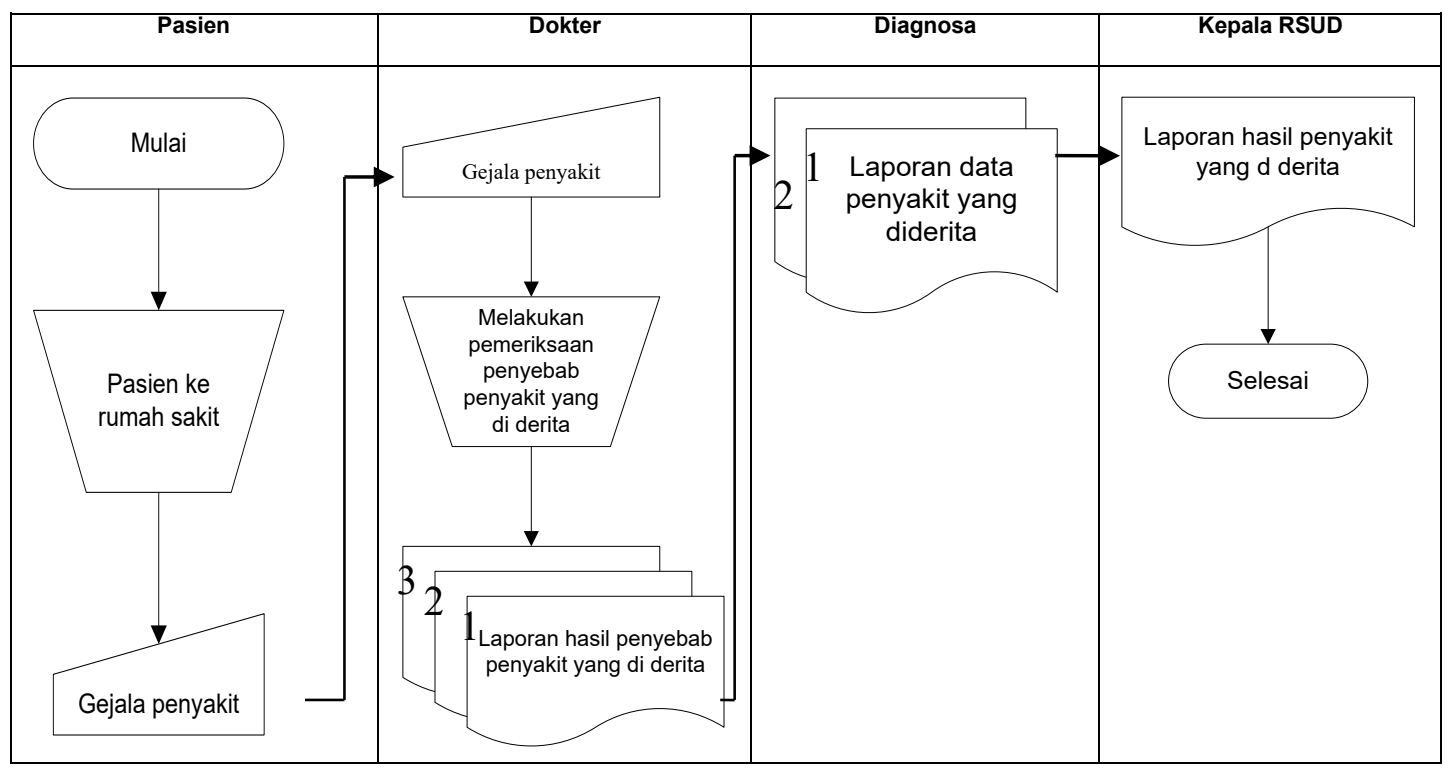


Jurnal IImiah ILKOM Volume 9 Nomor 3 Desember 2017

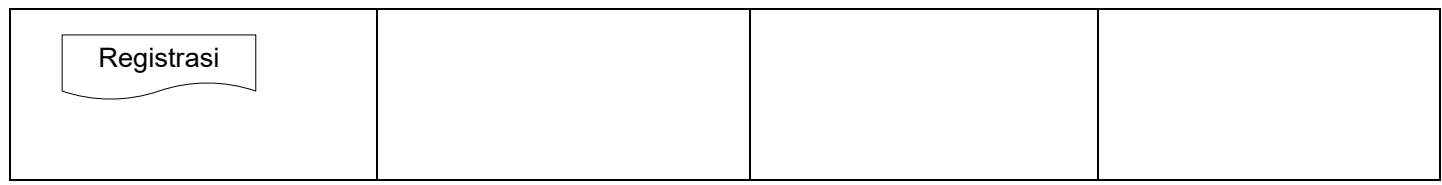

Gejala dan Jenis Penyakit

Gambar 1. Analisis Sistem Berjalan

Adapun gejala-gejala yang terdapat pada Penyakit Diabetes Melitus dapat dilihat pada Tabel 1 berikut:

\begin{tabular}{|l|l|}
\multicolumn{2}{|c|}{ Tabel1. Gejala Penyakit } \\
\hline KODE & \multicolumn{1}{|c|}{ GEJALA PENYAKIT } \\
\hline G001 & Usia $<30$ Tahun \\
\hline G002 & Kadar Gula darah rendah \\
\hline G003 & Luka yang sulit sembuh \\
\hline G004 & Badan terasa lemas \\
\hline G005 & Umur $>$ 30 tahun \\
\hline G006 & Kadar gula tinggi \\
\hline G007 & Kegemukan (obesitas) \\
\hline G008 & Pola makan tidak teratur \\
\hline G009 & Sering haus dan lapar \\
\hline G010 & Sering kencing \\
\hline
\end{tabular}

Jenis-jenis penyakit pada Diabetes Melitus dapat dilihat pada tabel 2 berikut:

Tabel 2.Jenis Penyakit

\begin{tabular}{|c|l|}
\hline KODE & \multicolumn{1}{|c|}{ JENIS PENYAKIT } \\
\hline P001 & Diabetes Melitus Tipe I \\
\hline P002 & Diabetes Melitus Tipe II \\
\hline
\end{tabular}

\section{Diagnosa Penyakit Diabetes Melitus}

Metode yang digunakan dalam sistem pakar ini adalah metode kepastian (certainty factor). Certainty Factor (CF) menujukkan ukuran kepastian terhadap suatu fakta atau aturan. Berikut rancangan Diagnosa Penyakit Diabetes Melitus :

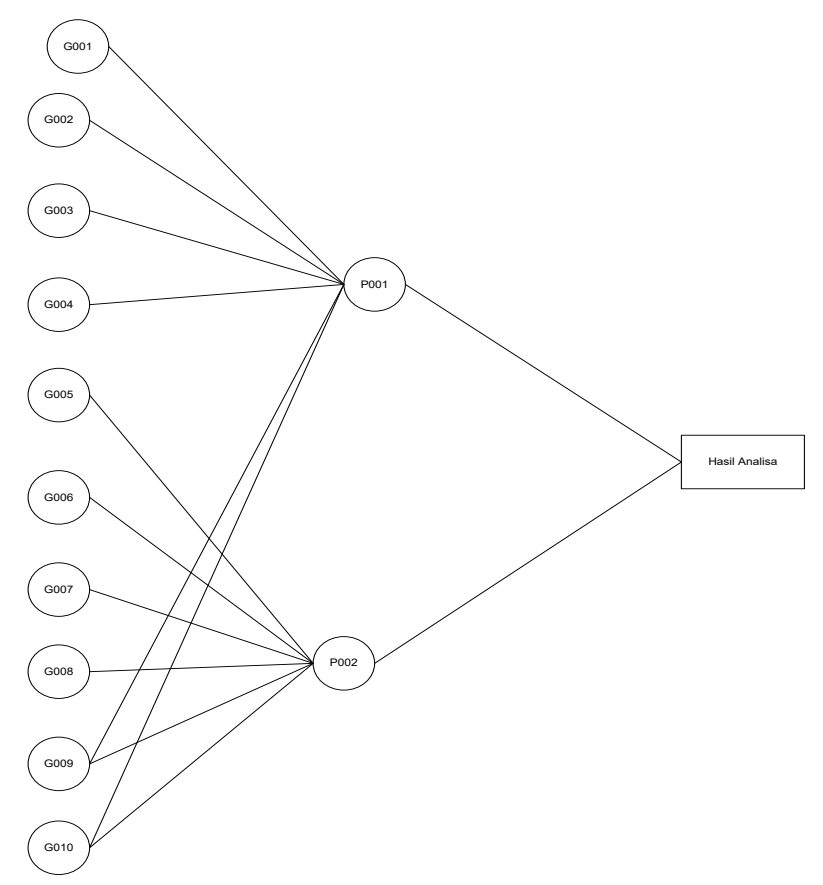

Gambar 2.Relasi Diagnosa Penyakit Diabetes Melitus 


\section{Jurnal IImiah ILKOM Volume 9 Nomor 3 Desember 2017}

Untuk P001 merupakan jenis penyakit Diabetes Melitus Tipe I yang gejala-gejalanya terdiri dari G001, G002, G003, G004, G009, dan G010. sedangkan P002 merupakan jenis penyakit Diabetes Melitus Tipe II yang gejalanya terdiri dari : G005, G006, G007, G008, G009, G010

\subsection{Langkah-Langkah Menjalankan Sistem}

Berikut ini adalah tampilan menu Home yang merupakan tampilan utama:

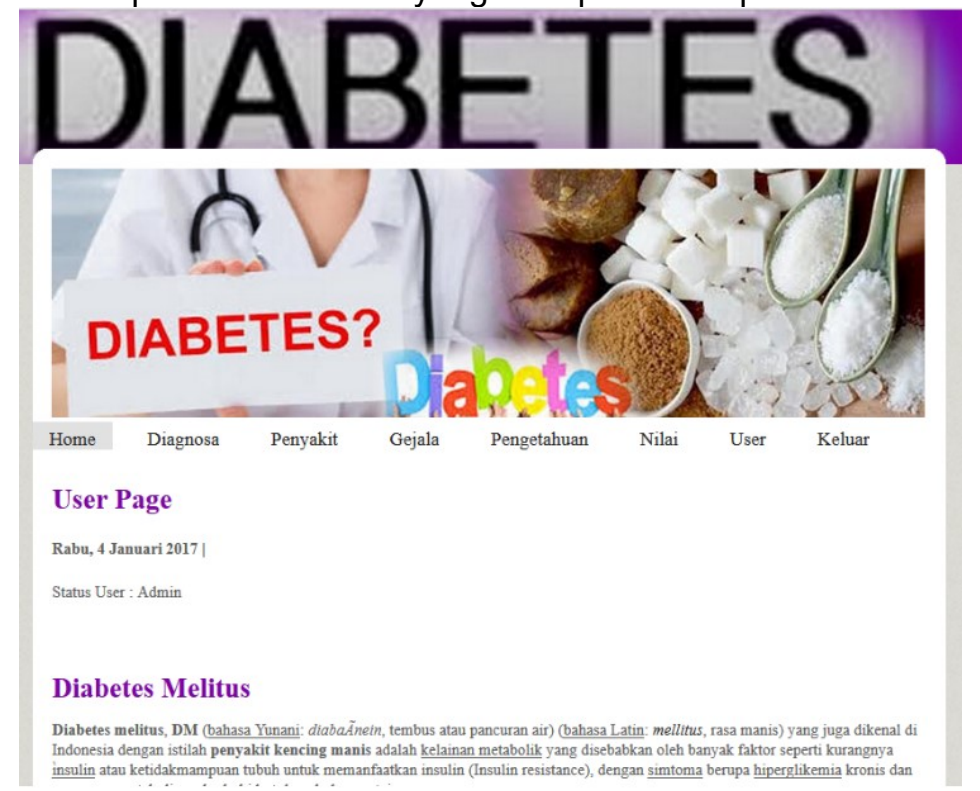

Gambar 3.Halaman menu utama

Menu Home yang merupakan tampilan utama untuk halaman admin dimana menu ini berisi tentang informasi waktu akses dan penjelasan detail tentang Penyakit Diabetes Melitus.

\section{Halaman Menu Diagnosa}

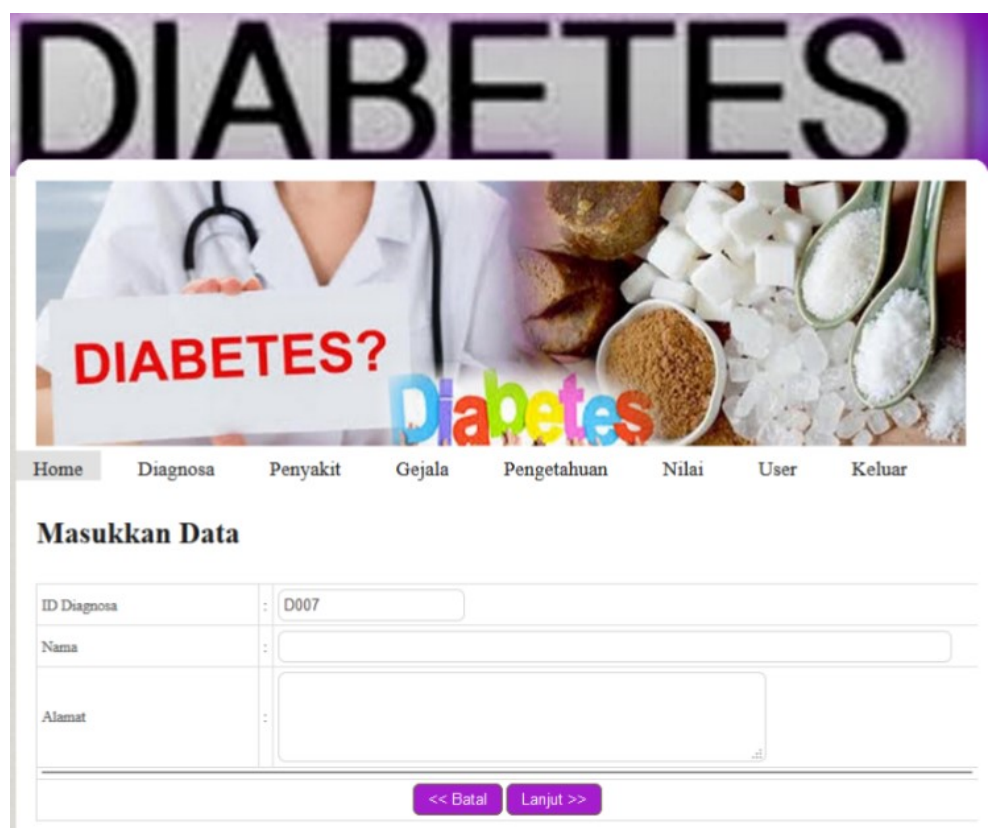

Gambar 4.Halaman menu Diagnosa

Halaman ini merupakan tampilan ketika user mengklik menu Diagnosa. Menu diagnosa digunakan untuk melakukan proses diagnosa, tapi sebelum proses diagnosa dilakukan harap memasukkan data pasien terlebih dahulu. 


\section{Halaman Menu Penyakit}

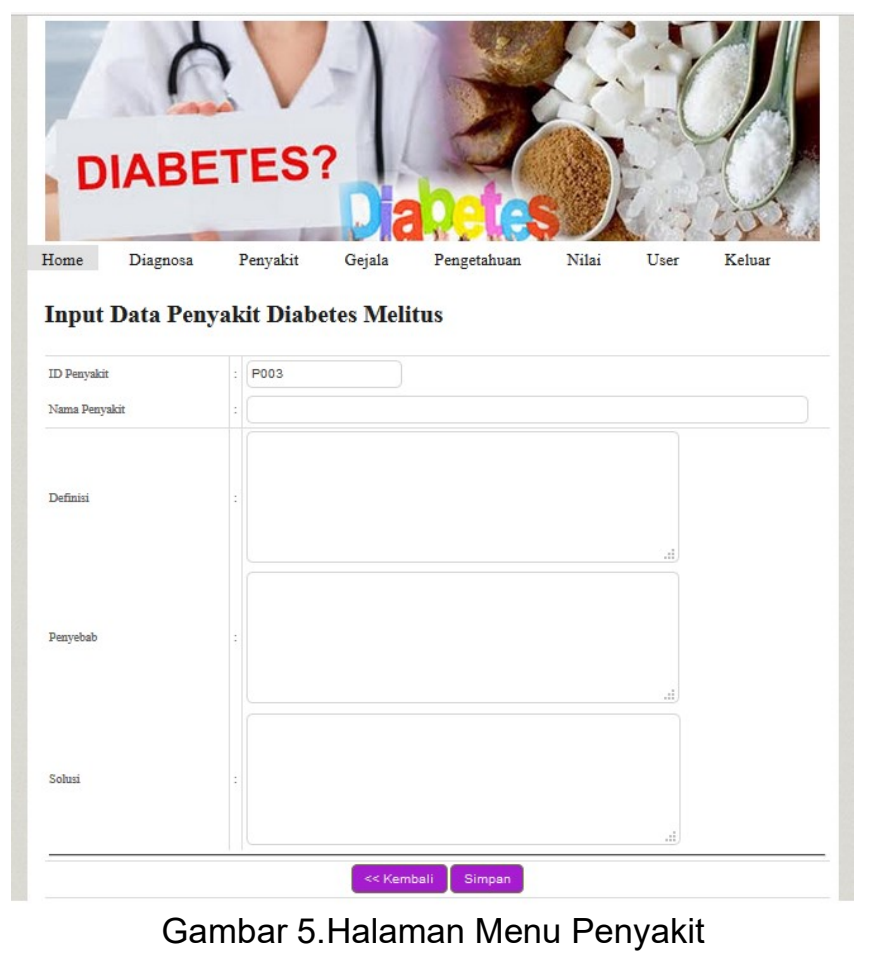

Tampikan diatas adalah tampilan halaman menu penyakit, dimana admin akan melakukan penginputan data penyakit Diabetes Melitus berdasarkan Nama Penyakit, penyebab dan solusi yang akan diberikan setelah proses diagnosa. Cara penginputannya :Silahkan input data id Penyakit, Nama Penyakit, Definisi, penyebab dan solusi. Setelah selesai mengisi silahkan klik tombol Simpan untuk mengimpan data, atau tekan tombol Kembali untuk membatalkan penginputan data penyakit.

\section{Halaman Menu Gejala}

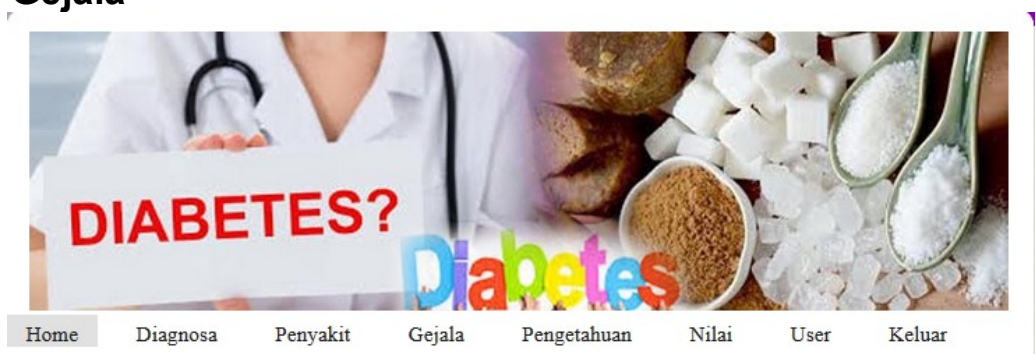

Input Gejala

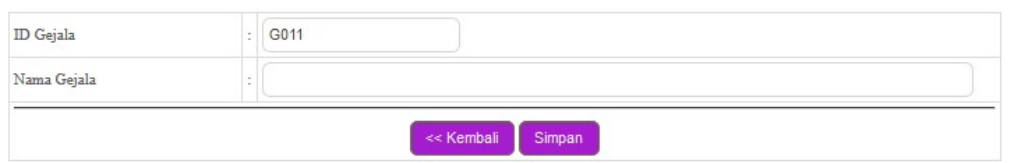

Gambar 6.Halaman menu gejala

Halaman menu Gejala merupakan halaman yang menampilkan tentang daftar Gejala Penyakit Diabetes Melitus. Silahkan input data gejala yang terdiri dari Id Gejala dan Nama Gejala.Setelah selesai mengisi silahkan klik tombol Simpan untuk mengimpan data, atau tekan tombol Kembali untuk membatalkan penginputan data gejala. 


\section{Jurnal IImiah ILKOM Volume 9 Nomor 3 Desember 2017}

\section{Halaman Menu Pengetahuan}

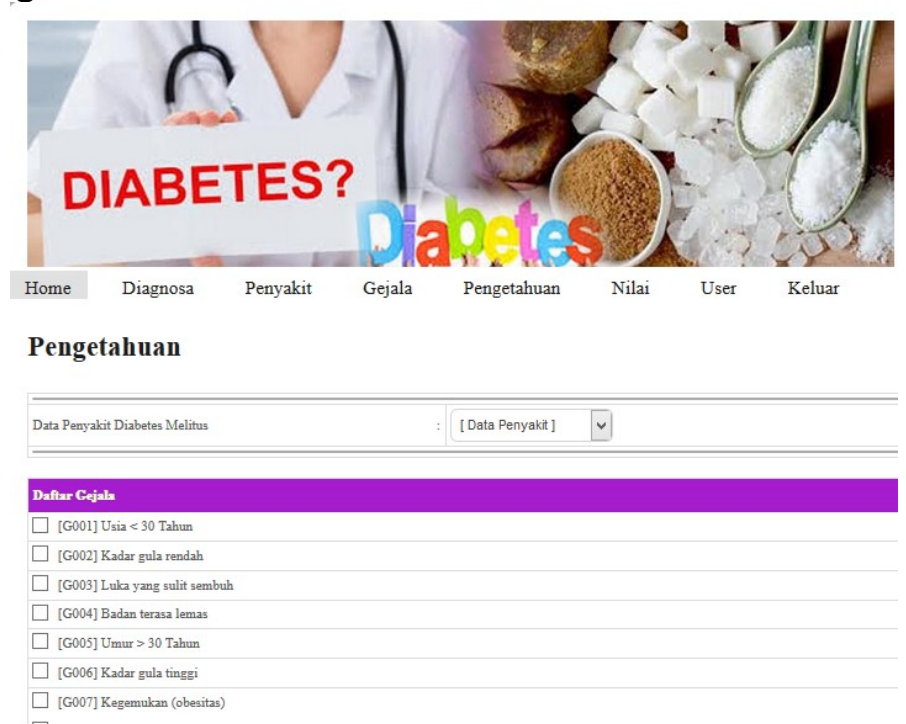

Gambar 7.Halaman menu pengetahuan

Menu Pengetahuan digunakan untuk menentukan basis aturan atau relasi antar jenis penyakit dan gejala, terlebih dahulu input Data Penyakit Diabetes Melitus kemudian pilih dan isi daftar gejala yang sesuai.

\section{Halaman Menu Nilai}

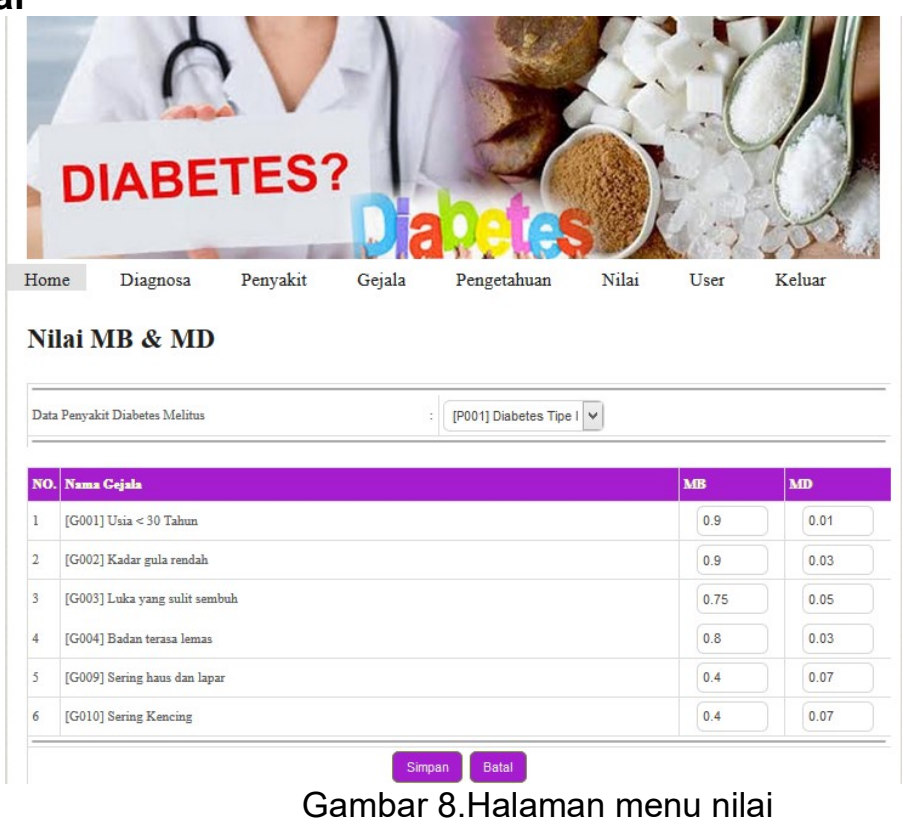

Menu Nilai, digunakan untuk menentukan nilai MB dan MD dari masing-masing penyakit berdasarkan gejala yang ada. Terlebih dahulu pilih Data Penyakit Diabetes Melitus kemudian isi nilai $\mathrm{MB}$ dan MD

\section{Kesimpulan dan Saran}

\subsection{Kesimpulan}

Dari perancangan aplikasi ini penulis dapat mengambil beberapa kesimpulan, diantaranya adalah sebagai berikut :

1. Dapat dibuat cara merekayasa Sistem pakar Diagnosa Penyakit Diabetes Melitus pada RSUD Bumi Panua. 


\section{Jurnal IImiah ILKOM Volume 9 Nomor 3 Desember 2017}

2. Sistem pakar ini sudah direkayasa dapat digunakan untuk Diagnosa Penyakit Diabetes Melitus pada RSUD Bumi Panua.

3. Sistem Pakar ini dirancang untuk membantu para penderita Diabetes Melitus.

\subsection{Saran}

Adapun saran dari penulis untuk pengembangan sistem ini kedepan yaitu Sistem pakar ini perlu dikembangkan lagi ke dalam bentuk aplikasi portable ataupun aplikasi berbasis android sehingga jangkauan masyarakat terhadap sistem ini dapat lebih luas lagi.

\section{Daftar Pustaka}

[1] Maulana, Mirza. 2012. Mengenal Lebih Mengenai Diabetes Melitus. Yogyakarta: Nuha Media

[2] Merlina, Nita, M.Kom., \&Rahmat Hidayat, S.Kom. 2012.PerancanganSistem Pakar. Yogyakarta :Ghalia Indonesia.

[3] Sutojo, T., dkk. 2011. Kecerdasan Buatan. Yogyakarta: Andi.

[4] PERKENI. 2011. Naskah Lengkap :Simposium Diabetes Melitus dan Dislipidemi. Makassar : Perkumpulan Endokrinologi Indonesia 